\title{
Adenosine regulates radiation therapy-induced anti-tumor immunity
}

\author{
Erik Wennerberg ${ }^{*}$, Noriko Kawashima, Sandra Demaria \\ From 30th Annual Meeting and Associated Programs of the Society for Immunotherapy of Cancer (SITC 2015) \\ National Harbor, MD, USA. 4-8 November 2015
}

Radiation therapy (RT) induces immunogenic cell death and dose-dependent release of ATP in the tumor microenvironment (TME), triggering maturation and activation of tumor-resident dendritic cells (DCs). However, extracellular ATP is rapidly catabolized to adenosine by ectonucleotidases CD39 and CD73, which are expressed by tumor cells and immune cells in the TME. Adenosine has pleiotropic immunosuppressive effects and inhibits activation of DC and effector T cells, while promoting regulatory $\mathrm{T}$ cells (Tregs). Here, we tested the hypothesis that conversion of ATP to adenosine hinders generation of effective anti-tumor immunity by high dose RT, reducing its synergy with anti-CTLA-4 antibody.

$\mathrm{BALB} / \mathrm{c}$ mice were inoculated s.c. with $1 \times 10^{5}$ TSA carcinoma cells on day 0 and assigned to treatment with: (1) control mAb; (2) anti-CD73 (TY/23); (3) TY/23+antiCTLA-4 (9H10); (4) RT; (5) RT+TY/23; (6) RT+9H10; (6) $\mathrm{RT}+\mathrm{TY} / 23+9 \mathrm{H} 10$. TY/23 $(200 \mu \mathrm{g})$ was administered i.p. every 4 days starting on day 11 . RT was given locally as single 20 Gy dose on day 12 . $9 \mathrm{H} 10(200 \mu \mathrm{g})$ was given i.p. on days 11,14 and 17 . On day 18 , some tumors were harvested for flow cytometry analysis of DC and T cells. Mice were monitored for tumor growth/regression.

In irradiated tumors, CD73-blockade reduced the percentage of Tregs within the tumor-infiltrating $\mathrm{CD} 4^{+} \mathrm{T}$ cell population $(7.9 \pm 2.5 \%$ in $\mathrm{RT}+\mathrm{TY} / 23$ vs $20 \pm 0.8 \%$ in $\mathrm{RT}, \mathrm{p}<$ $0.01)$ while increasing $\mathrm{CD} 8{ }^{+} \mathrm{T}$ cells $(38.3 \pm 0.1 \%$ in $\mathrm{RT}+\mathrm{TY} /$ 23 vs $17.3 \pm 4 \%$ in RT, $p<0.05$ ). Among intratumoral DCs $\left(\mathrm{CD} 11 \mathrm{c}^{+} \mathrm{MHCII}{ }^{+}\right)$, the $\mathrm{CD} 8 \mathrm{a}^{+} \mathrm{DC}$ subpopulation was increased after CD73-blockade $(37.9 \pm 15.7 \%$ in $\mathrm{TY} / 23+\mathrm{RT}$ vs $11.3 \pm 4.9 \%$ in $\mathrm{RT}, \mathrm{p}<0.01)$. Importantly, in irradiated mice, TY/23-administration enhanced activation of DCs and effector $\mathrm{T}$ cells, shown by increased CD40 expression on $\mathrm{CD} \mathrm{a}^{+}$DCs (MFI: $218 \pm 1$ in $\mathrm{RT}+\mathrm{TY} / 23$ vs $54 \pm 41$ in $\mathrm{RT}, \mathrm{p}<0.05)$ and increased CD69 expression on CD8 ${ }^{+}$

\footnotetext{
Department of Pathology, New York University School of Medicine, New York, NY, USA
}

Submit your next manuscript to BioMed Central and take full advantage of:

- Convenient online submission

- Thorough peer review

- No space constraints or color figure charges

- Immediate publication on acceptance

- Inclusion in PubMed, CAS, Scopus and Google Scholar

- Research which is freely available for redistribution 